\title{
USING THE METHODOLOGICAL PROCEDURES FOR WATER EROSION RISK AREAS IDENTIFICATION FOR SUSTAINABLE LAND USE
}

\author{
VIERA PETLUŠOVÁ ${ }^{1}$, PETER PETLUŠ ${ }^{1}$, ERIKA TOBIAŠOVÁ ${ }^{2}, J^{\prime}$ RAJ HREŠKO ${ }^{1}$ \\ ${ }^{1}$ Department of Ecology and Environmental Sciences, Faculty of Natural Sciences, Constantine the Philosopher Univer- \\ sity, Nitra, Tr. A Hlinku 1, 94974 Nitra, Slovak Republic; e-mail: vpetlusova@ukf.sk, ppetlus@ukf.sk, jhresko@ukf.sk \\ ${ }^{2}$ Department of Soil Science, Faculty of Agrobiology and Food Resources, Slovak University of Agriculture in Nitra, \\ Tr. A. Hlinku 2, 94976 Nitra, Slovak Republic; e-mail: erika.tobiasova@uniag.sk
}

\begin{abstract}
Petlušová V., Petluš P., Tobiašová E., Hreško J.: Using the methodological procedures for water erosion risk areas identification for sustainable land use. Ekológia (Bratislava), Vol. 39, No. 2, p. $145-158,2020$.

The countries of the European Union have joined, inter alia, soil protection in the Common Agricultural Policy (hereinafter referred to as CAP). Accelerated soil erosion is a problem resulting from inappropriate land management, which affects both the presence of organic matter and the soil structure. The tool for elimination of negative impacts on soil can be its sustainable use. This requires the use of an accurate system to improve its condition. The first step should be problem identification and localisation. The research is aimed at the identification of water erosion risk areas by using selected methodological procedures. The research area was located at the intensively used hilly land of the Southwestern Slovakia. The digitisation of the manual interpretation of erosion risk areas with the use of aerial photos, erosion modelling, chemical analysis of soil organic matter (SOM) and analysis of soil structure were used. Verification was implemented via the field research with the use of the soil probes. Methods affirmed significant presence of the water erosion in the area. Efficient identification of erosional processes is possible via combination of presented methods by taking into consideration geological, geomorphological, pedological and geographical conditions and the use of the area over a longer period of time. The results of using methods that ensure accurate and effective localisation of erosion surfaces can be used for sustainable land use and its conservation.
\end{abstract}

Key words: digitization of the erosion surface, water erosion modelling, visual identification of the erosion, carbon sequestration and movement, hilly lowland.

\section{Introduction}

Sustainable management of natural resources has become an essential attribute in eliminating effects of climate change, preserving biodiversity and improving environment. Soil as a natural resource used primarily for agricultural purposes undergoes a process that threatens its quality and functions. It is endangered by erosion, compaction, loss of nutrients, increased 
acidity, low organic matter content and areal land take up for non-agricultural purposes. It leads to disruption or disappearance of ecosystems and important elements of the country. The application of sustainable and soil conservation innovative technologies of soil management can be ensured by lowering down the impact of negative effects.

The Common Agricultural Policy (CAP) has introduced the promotion of sustainable land use at the EU level. It supports soil management research and innovation. The aim is to identify and evaluate perspective land use systems that improve soils' condition and take into account the socio-economical aspect.

Following the principles and objectives of the CAP, the research is focused on the identification of water erosion using various methods. Testing of methods took place in the lowland type of hilly land.

In Slovakia, hills have suitable climatic and soil conditions for agricultural use. Gradual intensification of land use in Slovak hills that is related to the development of agricultural activities leads not only to the change of the landscape structure but mainly to the development of soil degradation. It promotes the acceleration of processes associated with surface run-off by formation and development of water erosion.

Accurate identification of areas endangered by water erosion is one of the fundamental attributes entering into sustainable land management proposals. Šarapatka and Niggli (2008) stated that if it needs to meet the requirements of sustainable land management, more soil drainage than the amount of soil that will be created should not be allowed to maintain the land for future generations. Soil drainage brings many negative phenomena. Bielek (2017) stated that the most important potentials of soil functions, especially biomass production, water filtration and hydrological rainfall cycle in the area, are reduced directly where the erosion took place, reducing the overall utility value of the soil habitat. Outside of the area where erosion takes place, there are threats such as unwanted supply of soil matter, pollutants, nutrients and agrochemicals and sediments damaging ecosystems. Thus, the erosive processes represent a significant negative factor threatening especially the surface soil horizon. Its removal is the ultimate and irreversible state that leads to decline in agricultural land yields and significant economic losses, which may not only have economic but also social consequences. Solution of this problem requires an active research on water erosion. Zachar (1970, 1982), Fulajtár and Janský (2001), Stankoviansky (2000, 2001), Kenderessy (2012) and Petlušová et al. $(2016,2017)$ dealt with the research of erosion in conditions of Slovakia. The development of water erosion is conditioned by morphological and morphometric features of the relief. Faltan et al. (2017), Panagos et al. (2015), Zeleňáková and Jakubíková (2010), Kirkby et al. (2002) and Styk (2002) highlighted the importance of the slope angle and land use. The importance of the erosionaccumulation processes is also highlighted by the extent of elaboration of this issue in many foreign scientific works that use innovative information systems. One of the dominant systems playing an important role in determining erosion-accumulation processes is remote sensing of the Earth (hereinafter referred to as RSE) (Biswas et al., 1999; Bouaziz et al., 2011; Al-Abadi et al., 2016). Research on erosion processes is progressively improving. New possibilities and procedures for identifying water erosion are being sought, which could be generalised and applied in practice. However, the choice of methods depends 
on the purpose of the research and may be thematically and territorially designed. The high variability of erosion research methods causes that most of works have a specific focus (pedological, geographical, hydrological, etc.). Signs of water erosion are not only quantitative but also qualitative. The identification of these changes based on the selected soil organic matter (SOM) parameters and soil structure reflects the manifestations of this form of erosion in the landscape as well as changes in the soil production capacity affected by water erosion (Pintaldi et al., 2018; Wang et al., 2018; Abera, Assen, 2019). The removal of particles from the humus surface horizon, the richest in organic matter, not only reduces the thickness of this active soil profile (Conforti et al., 2013) but also deteriorates other soil properties (Šarapatka et al., 2018) because they are closely related to the SOM. In this context, it is necessary to consider not only the reduction of organic carbon content but also its distribution in soil aggregates, which is closely related to carbon sequestration (Li et al., 2017). Soil structure and SOM together with soil texture are part of the soil erodibility factor, which is a part of the universal equation for the calculation of the average long-term soil loss (Wischmeier, Smith, 1978).

The aim is to present several procedures for the optimal identification of water erosion processes. The results can enter into sustainable land use proposals based on the precise and effective localisation of erosion risk areas that require a specific approach when they are used.

\section{Material and methods}

The model area is the intensively agriculturally used area of the SE part of Podunajská nížina lowland, which is formed by the spur of Hronská pahorkatina hills, in the cadastral areas of Lubá and Belá villages. The current character of land use is the result of the intensification of agriculture with a predominant abundance of large-scale arable field. Predominant soil types are brown earth soils (Orthic Luvisols), regosols (Regosols) and chernozems. The area is part of Podunajská pahorkatina hills. It has the character of medium to slightly rugged hills with an altitude of 110-250 $\mathrm{m}$ asl. The selection of the area was conditioned by the presence of significant erosion processes.

Following methods were used to test methodologies for identifying water erosion processes:

Digitisation of erosion processes manifestations using aerial photos with the aim of finding area extension of water erosion

Spatial expansion of erosion and accumulation areas was realised by visual evaluation and interpretation of aerial photos, which are a proven possibility of their application in the field. Identification of erosion processes as colour differences was realised visually based on the aerial photos from six time periods $(1949,1970,2006,2011,2014$ and 2015). The images are from different seasons, thus partially eliminating the effect of the vegetation cover (visual expression of erosion partially overlapping seasonally). A surface assessment of the quantitative representation of erosion areas was obtained by vectorisation of light amoebic formations on aerial images. Significant areas where erosion took place in the past and is still going on or where erosion occurred only in the past or now were identified. They were named as actual and potential erosion risk areas (Fig. 1).

\section{Modelling of water erosion}

Modelling was realised as a calculation of the potential average annual loss of soil and the determination of the material removal from the slope. The digital terrain model 10×10 $\mathrm{m}$ was used, derived from the basic contour maps of 1:10 000. The rainfall erosivity factor ( $\mathrm{R}$ factor) was identified from the climate map (Lapin et al., 2002) and a database of selected $\mathrm{R}$ factor values (Ilavská et al., 2005). To determine the soil erodibility factor (K factor), a database of selected $\mathrm{K}$ factor values was used (Ilavská et al., 2005). The calculation of the topographical factor, combined slope length and slope inclination (LS factor), was created in GRASS GIS (module r.watershed). The crop management factor (C factor) was used according 


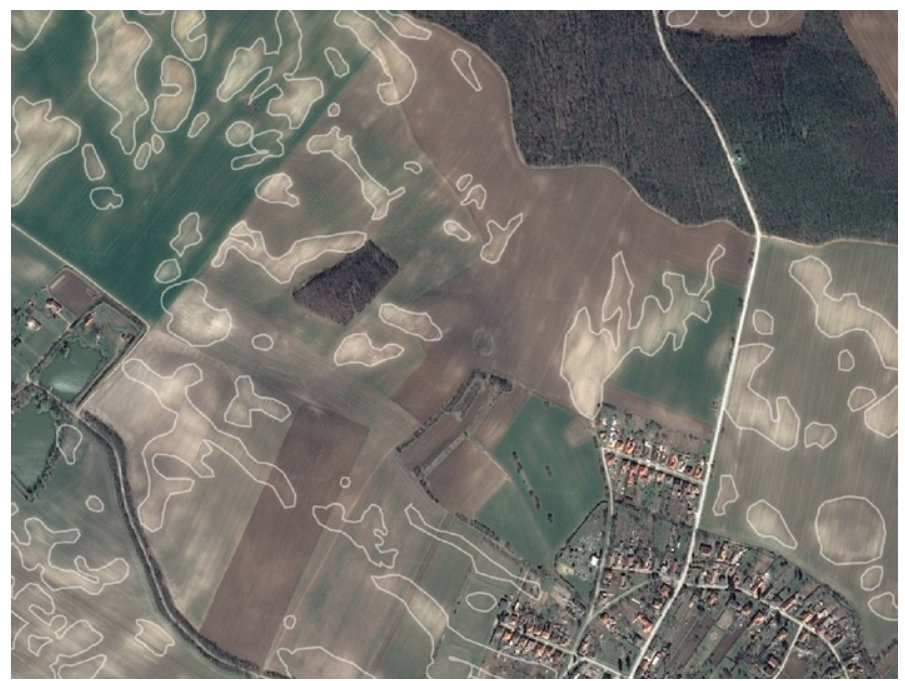

Fig. 1. Areas realistically and potentially endangered by water erosion (resource: orthophoto map (C) EUROSENSE). to Malíšek (1992). The conservation practice factor ( $\mathrm{P}$ factor) was determined accordingly (Ilavská et al., 2005).

For the determination of the 'average' annual loss of soil, the so-called universal equation for long-term loss of water by water erosion - USLE by Wischmeier and Smith (1978) - was used. The value of permissible loss of land serves to determine the erosion risk degree of the land. It is defined as a maximum intensity of soil erosion that allows to maintain sufficient level of the soil fertility on a long-term basis, which is economically available (Janeček et al., 2012). The categorisation of calculated data was based on four categories of average annual soil loss: no to weak soil loss (0-4 t/ha/

year), medium soil loss (4-10 t/ha/year), high soil loss (10-30 t/ha/year) and extreme soil loss (>30 $t /$ ha/year). They are listed in Act No. 220/2004 Coll. on the limit values for the erodibility categories of agricultural soils.

\section{Modelling the drainage direction of the material}

The determination of the direction of material removal from the slope was based on the methodology of Miklós et al. (1997). The methodology was adapted considering the assumption of transport of soil particles along the slope and not their accumulation. The relief shapes calculated in the geographic information system (hereinafter referred to as GIS) environment based on the digital relief model were used. The digital relief model was derived from the basic contour maps of the SR at a scale of 1:10 000. For vertical and horizontal ruggedness, the following categories have been determined: concave surfaces, sunken with slow-drainage, flat surfaces, non-curved and convex surfaces and convex surfaces with accelerated drainage. By the synthesis of vertical and horizontal curvature, the basic forms of the relief have been found to be critical in determining run-off ratios and for our needs to determine the potential material drainage from the slope. The basic forms of the relief together with the slope of the area were used in the calculation of material removal from slopes.

\section{Identification and verification of water erosion with the use of soil probes}

An Edelman auger with drill capacity of up to $500 \mathrm{~cm}$ with a diameter of $50 \mathrm{~mm}$ was used for the identification. The thickness of the humus horizon, the presence of soil horizons, the depth of turning the soil over, the character of the soil-forming substrate and the thickness of the accumulated material were verified. On the basis of the ascertained data, soils endangered by erosion (light surfaces) or soil accumulated in concave slope areas were identified as a manifestation of the transport of soil particles along the slope. There were 51 soil probes realised. Probes were located irregularly throughout the territory on slopes with expected erosion or accumulation (Fig. 2).

\section{Soil erosion in the context of soil organic matter and soil structure analysis}

In assessing the effects of water erosion through SOM and soil structure, several of their parameters, such as total organic carbon (TOC), labile $\left(\mathrm{C}_{\mathrm{L}}\right)$ and non-labile $\left(\mathrm{C}_{\mathrm{NL}}\right)$ carbon, humic substances (HS) and fractional composition of soil 
aggregates, were used. Soil structure vulnerability coefficient $\left(\mathrm{K}_{\mathrm{v}}\right)$ (Valla et al., 2000), clogging index (I) (Lal, Shukla, 2004) or critical content of SOM (S) (Valla et al., 2000) were also used, on which effects of erosion-accumulation processes were fully manifested. At the same time, carbon sequestration was analysed. One of the main mechanisms of carbon sequestration is its increase in carbon-rich macro-aggregates (Six et al., 2002), which also implies their favourable size distribution. SOM analysis was performed on soil samples collected from three parts of the slope: the upper convex part, the slope and the accumulation concave part. On one slope (Fig. 2), soil samples were also taken in a line, from top to bottom along the slope. The sampling points were $20 \mathrm{~m}$ apart.

\section{Results}

Digitisation of erosion processes manifestations using aerial photos with the aim of finding area extension of water erosion

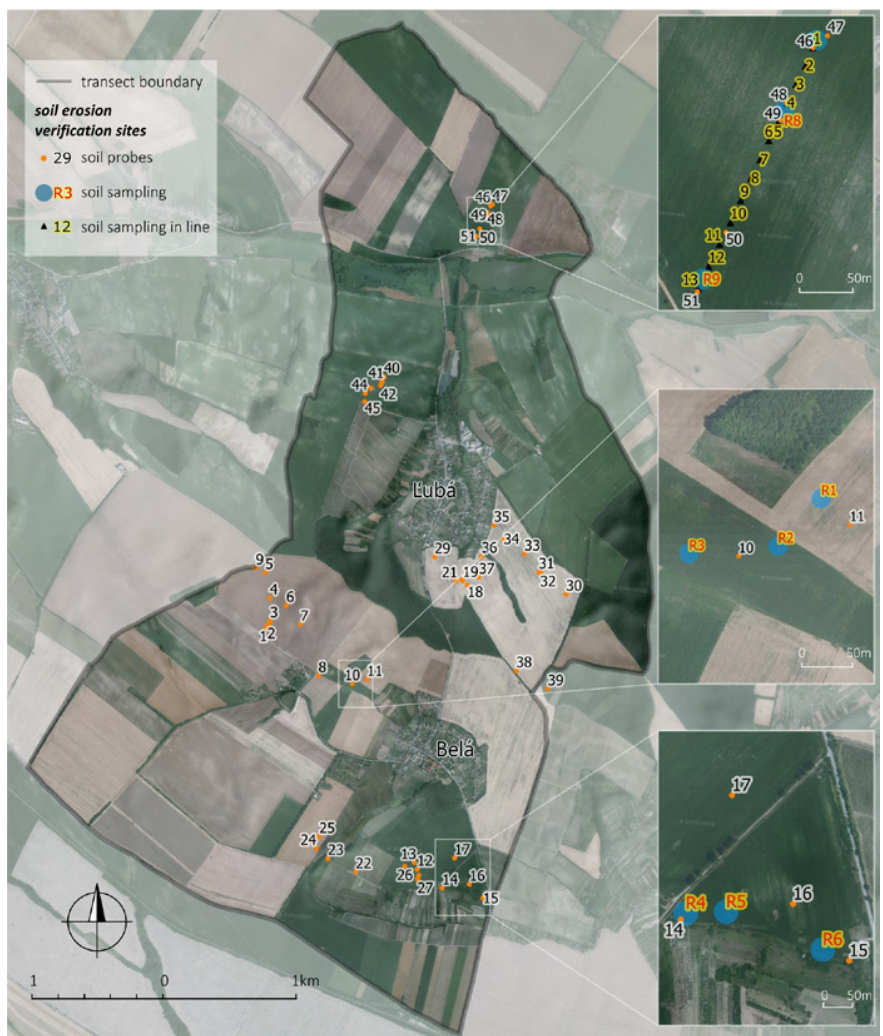

Fig. 2. Soil probes and sampling sites (resource: orthophoto map (C) EUROSENSE).

The area manifestation of water erosion in the period 1949-2016 increased by 130.56 ha $(8.88 \%)$. The erosion areas have increased by changing land use because of the change of narrow strip fields to large-strip fields. Areas realistically and potentially endangered by water erosion represented 408.44 ha $(27.78 \%)$ in total. These areas (Fig. 3) can be used in other procedures for the detection of water erosional processes.

Demarcated erosion surfaces were used in the process of partial syntheses, which express their relationships with the relief parameters (slope, exposure and relief shapes) and the type of land use change, and also with the values of soil removal or with material removal directions and so on (Petlušová et al., 2016). The slope is given as demonstration of research results. Areas where slope significantly affects or does not affect the spread of erosion have been identified via the combination of realistically endangered surfaces and slope. The slope was evaluated according to five categories. In the $0-1^{\circ}$ category, actual erosion was abundant on 25.44 ha (16.9\%). These are areas that are used to grow spring and winter cereals, oilseeds, leguminous seeds and the like. In the $1-3^{\circ}$ category, erosion was on 66.44 ha (17.70\%). In terms of land use, these sites were mainly used as arable land and also as permanent grassland. In the slope category $3-7^{\circ}$, erosion was on 


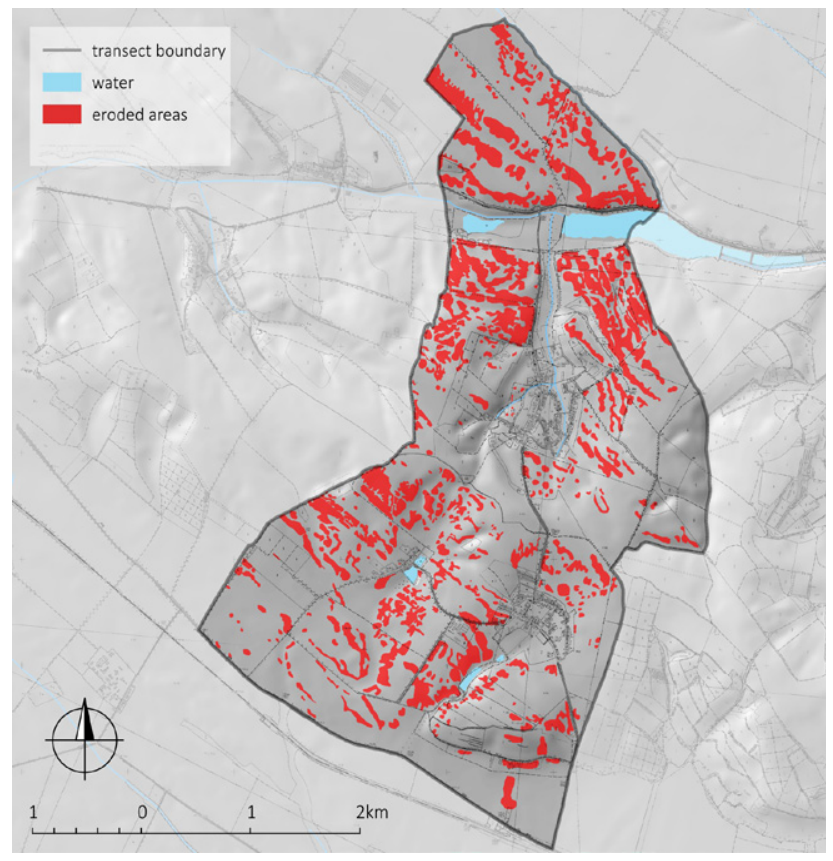

Fig. 3. Surfaces endangered by water erosion (resource: DTM 10x10, Esprit s. r. o; Basic map of SR 1: 10 000).

218.90 ha (30.27\%). Major part of area comprised arable soil. Vineyards are considered to be a significant element. In the $7-12^{\circ}$ category, erosion was found on 80.69 ha $(39.83 \%)$. Suitability of soil types enables to use this area as arable soil despite the fact that the risk of erosion processes occurrence is high. Similarly, it is in the slope category of $12^{\circ}$ or more, which was abundant on 4.22 ha $(22.40 \%)$. The results show that the slope inclination determines the occurrence of areas with a realistic presence of soil erosion.

\section{Modelling of water erosion}

Water erosion modelling results in spatial expression of areas with potential average annual soil loss. Significant manifestations of erosion were found in moderately rugged hilly parts of the area with a slope of higher than $3^{\circ}$, but mostly where the slope of the area was $7-12^{\circ}$. In these parts, categories 2 and 3 (medium and high soil loss) prevail according to the data obtained in the soil loss calculations (Fig. 4). The area has long been used as large-scale intensively used arable fields. In one site, in category 3 with high soil loss, the forest is currently there.

Three categories of soil removal were identified: weak, medium strength and strong. On the greater part of the area, there are abundant categories of medium strong to strong drainage, which significantly determines the drainage of soil particles and their accumulation in the concave parts of the area. Research has shown that soil is subject to erosion processes. During the monitored period, the surface was intensively farmed. Rapeseed and winter wheat were grown, and on the neighbouring soil complex with medium soil loss, maize was grown.

\section{Identification and verification of water erosion with the use of soil probes}

Soil erosion identification was carried out with 51 drilled soil probes. Verification of erosional processes with the use of soil probes shows that predominantly soil types, regosols, eroded brown earths and eroded chernozems, indicate the presence of erosion in at least three quarters of cases (Table 1). 
Soil probes also pointed out that in the lower accumulation slope parts and on the convex slope forms with a lower slope, the alluvial deposits (coluviosol-Colluvisols) were more than $2 \mathrm{~m}$ deep, indicating the downward movement of soil particles where they have been deposited.

Soil erosion in the context of soil organic matter and soil structure analysis

TOC content in both soil (Table 2) and soil aggregates (Table 3) was increasing in the direction from the top of the slope down, but humus quality (Table 2) had opposite tendency.

In the case of $\mathrm{C}_{\mathrm{L}}$ (Table 3) and $\mathrm{C}_{\mathrm{NL}}$ (Table 3) contents in water-resistant macro-aggregates (WSA), the situation was similar, thus increasing its content down the slope direction. At the

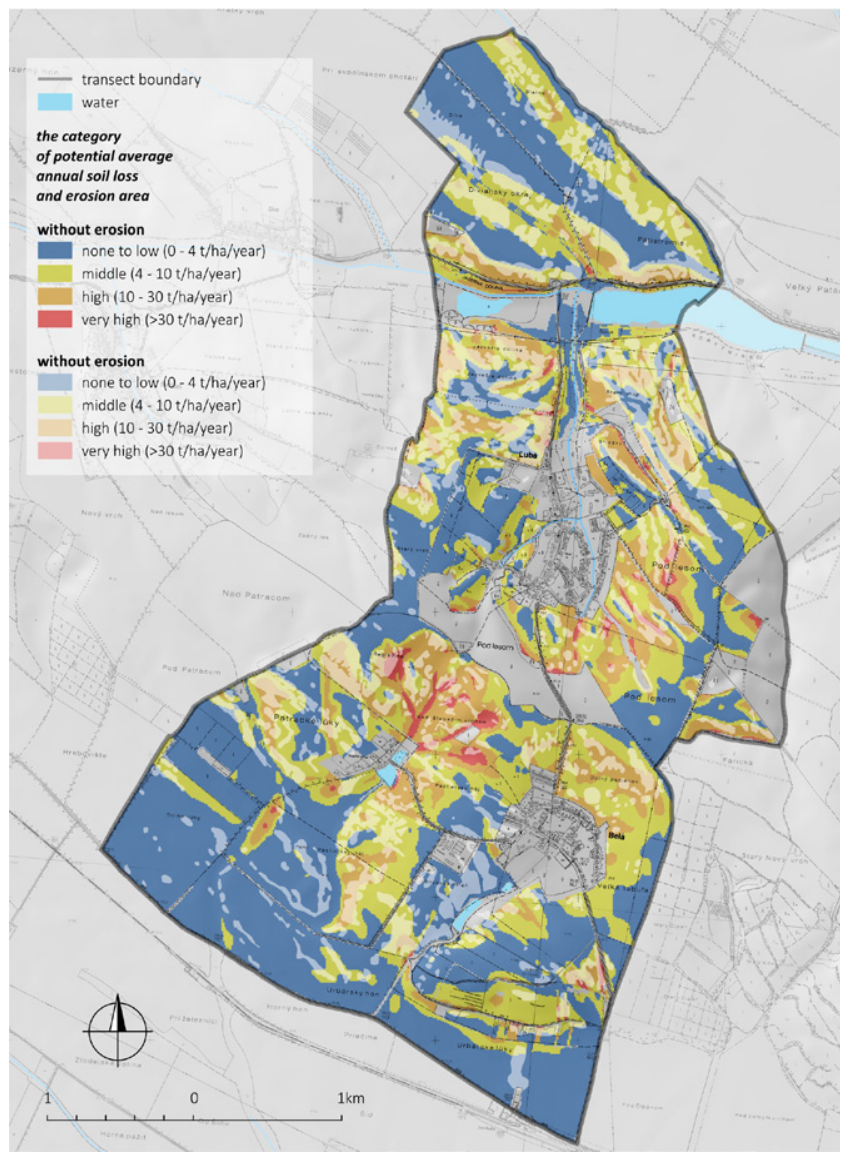

Fig. 4. Potential average annual soil loss (resource: DTM 10x10, Esprit s. r. o; Basic map of SR 1: 10 000; orthophoto map (C EUROSENSE). same time, organic carbon contents had a decreasing tendency from the larger fraction with its highest content to the smallest fraction of WSA with the lowest content. On the basis of carbon sequestration, the proportion of dry-sieved macro-aggregates (DSA; 1-7 mm) increased down the slope direction, and on the contrary, the content of the smaller $(<1 \mathrm{~mm})$ and larger $(>7 \mathrm{~mm})$ DSA fractions decreased (Table 3), which again points out not only the deterioration of the eroded top soil profile properties but, at the same time, similar the previous parameters, can also identify the erosion of the affected surfaces.

By linking the parameters that are part of the erodibility factor (SOM, soil structure and soil texture), further parameters that correspond to the manifestations of water erosion were obtained. Values of the soil structure vulnerability coefficient $\left(\mathrm{K}_{\mathrm{v}}\right)$ (Valla et al., 2000) and index of crusting ( $\mathrm{I}_{\mathrm{c}}$ ) (Lal, Shukla, 2004) were decreasing, and on the contrary, critical SOM content $\left(\mathrm{S}_{\mathrm{t}}\right)$ (Valla et al., 2000) increased downward the slope (Table 4). On the basis of these 
T a b l e 1. Soil types with erosion manifestation (E) and with no erosion manifestation (N).

\begin{tabular}{|c|c|c|}
\hline Probe No. & Soil Type Classification & $\begin{array}{c}\text { Erosion } \\
\text { Manifestation }\end{array}$ \\
\hline 1 & Cultivated Calcaric Regosols on neogene sediments & $\mathrm{E}$ \\
\hline 2 & Cultivated Calcaric Regosols on neogene sediments & $\mathrm{E}$ \\
\hline 3 & Cultivated Calcaric Regosols on neogene sediments & $\mathrm{E}$ \\
\hline 4 & Eroded Orthic Luvisols on neogene sediments & $\mathrm{E}$ \\
\hline 5 & Eroded Chernozems on neogene sediments & $\mathrm{E}$ \\
\hline 6 & Calcaric Regosols on neogene sediments & $\mathrm{E}$ \\
\hline 7 & Colluvisols & $\mathrm{E}$ \\
\hline 8 & Eroded Chernozems on loess & $\mathrm{E}$ \\
\hline 9 & Cultivated Calcaric Chernozems on loess & $\mathrm{N}$ \\
\hline 10 & Colluvisols & $\mathrm{E}$ \\
\hline 11 & Regosols on neogene sands & $\mathrm{E}$ \\
\hline 12 & Cultivated Orthic Luvisols on loess loam & $\mathrm{N}$ \\
\hline 13 & Regosols on weathered neogene gravels & $\mathrm{E}$ \\
\hline 14 & Decalcified Haplic Chernozems on loess & $\mathrm{E}$ \\
\hline 15 & Luvi-haplic Cernozems & $\mathrm{E}$ \\
\hline 16 & Cultivated Calcaric Regosols on loess & $\mathrm{E}$ \\
\hline 17 & Cultivated Calcaro Haplic Chernozems & $\mathrm{N}$ \\
\hline 18 & Regosols on loess & $\mathrm{E}$ \\
\hline 19 & Regosols on loess & $\mathrm{E}$ \\
\hline 20 & Eroded Orthic Luvisols (rubified) on loess & $\mathrm{E}$ \\
\hline 21 & Colluvisols & $\mathrm{E}$ \\
\hline 22 & Colluvisols & $\mathrm{E}$ \\
\hline 23 & Cultivated Calcaric Regosols on neogene sediments & $\mathrm{E}$ \\
\hline 24 & Cultivated Calcaric Regosols on neogene sediments & $\mathrm{E}$ \\
\hline 25 & Eroded Chernozems on loess & $\mathrm{E}$ \\
\hline 26 & Cultivated Chernozems on loess & $\mathrm{N}$ \\
\hline 27 & Eroded Chernozems on loess & $\mathrm{E}$ \\
\hline 28 & Arenic Chernozems on neogene sands & $\mathrm{N}$ \\
\hline 29 & Calcaric Regosols on loess & $\mathrm{E}$ \\
\hline 30 & Haplic Chernozems on loess & $\mathrm{N}$ \\
\hline 31 & Cultivated regosols on loess & $\mathrm{E}$ \\
\hline 32 & Eroded Chernozems on loess & $\mathrm{E}$ \\
\hline 33 & Eroded rubified soil (not classified) & $\mathrm{N}$ \\
\hline 34 & Eroded Chernozems on loess & $\mathrm{E}$ \\
\hline 35 & Colluvisols & $\mathrm{E}$ \\
\hline 36 & Rubified soil on loess (not classified) & $\mathrm{N}$ \\
\hline 37 & Haplic Chernozems on loess & $\mathrm{N}$ \\
\hline 38 & Eroded Chernozems on loess & $\mathrm{E}$ \\
\hline 39 & Haplic Chernozems on loess & $\mathrm{N}$ \\
\hline 40 & Eroded Regosols & $\mathrm{E}$ \\
\hline 41 & Cultivated regosols on loess & $\mathrm{E}$ \\
\hline 42 & Eroded Regosols & $\mathrm{E}$ \\
\hline 43 & Regosols on loess & $\mathrm{E}$ \\
\hline 44 & Haplic Chernozems & $\mathrm{N}$ \\
\hline 45 & Luvi-haplic Chernozems on loess & $\mathrm{N}$ \\
\hline 46 & Eroded Chernozems on loess & $\mathrm{E}$ \\
\hline 47 & Eroded Chernozems on loess & $\mathrm{E}$ \\
\hline 48 & Regosols on loess & $\mathrm{E}$ \\
\hline 49 & Eroded Chernozems on loess & $\mathrm{E}$ \\
\hline 50 & Eroded Chernozems on loess & $\mathrm{E}$ \\
\hline 51 & Colluvisols on neogene gravels & $\mathrm{E}$ \\
\hline
\end{tabular}

Resource: Terrain Research (2015-2017). 
$\mathrm{T} \mathrm{a} \mathrm{b}$ le 2 . Selected quantitative and qualitative parameters of soil organic matter.

\begin{tabular}{|l|c|c|c|c|c|}
\hline \multirow{2}{*}{$\begin{array}{l}\text { Part of the Slope/ } \\
\text { Parameters }\end{array}$} & $\begin{array}{c}\text { Total Organic } \\
\text { Carbon (TOC) }\end{array}$ & $\begin{array}{c}\text { Humic Substance } \\
\text { Carbon (HSC) }\end{array}$ & $\begin{array}{c}\text { Humic Acid } \\
\text { Carbon }\left(\mathbf{C}_{\mathrm{HA}}\right)\end{array}$ & $\begin{array}{c}\text { Fulvic Acid } \\
\text { Carbon }\left(\mathbf{C}_{\mathrm{FA}}\right)\end{array}$ & $\begin{array}{c}\mathbf{C}_{\mathrm{HA}} / \mathbf{C}_{\mathrm{FA}} \\
\text { Ratio }\end{array}$ \\
\cline { 2 - 6 } & $\mathbf{( \mathbf { m g ~ k g } ^ { - 1 } )}$ & $\mathbf{( \% )}$ & $\mathbf{( \% )}$ & $\mathbf{( \% )}$ & 1.95 \\
\hline R1 & 7530 & 38.11 & 26.16 & 12.95 & 1.15 \\
\hline R2 & 10810 & 39.59 & 25.64 & 17.91 & 1.13 \\
\hline R3 & 14570 & 43.17 & 23.79 & 14.19 & 1.70 \\
\hline R4 & 16980 & 37.99 & 26.01 & 18.70 & 1.26 \\
\hline R5 & 12570 & 44.74 & 40.10 & 30.95 & 1.89 \\
\hline R6 & 18900 & 70.06 & 24.21 & 12.20 & 1.50 \\
\hline R7 & 16810 & 36.41 & 21.15 & 13.88 & 0.95 \\
\hline R8 & 9220 & 35.03 & 21.14 & 15.95 & 1.01 \\
\hline R9 & 13480 & 37.09 & & & \\
\hline
\end{tabular}

Notes: R1, R4 and R7 - upper convex part; R2, R5 and R8 - slope; R3, R6 and R9 - accumulative concave part.

results, the least favourable state could be again considered on the top slope parts and basically with the downward trend.

The loss of soil structure and its tendency to erosion $\left(\mathrm{S}_{\mathrm{t}}<5 \%\right)$ was manifested in all cases and had a decreasing tendency. The tendency of SOM in the line is shown in Table 5.

On the slope, the quality and quantity of soil organic matter are changing. Organic carbon is shifted to the bottom of the slope. This indicates soil erosion, which affects other important soil components and functions.

\section{Discussion}

Using selected methods for identifying water erosion has shown that water erosion processes can be identified by several methods. However, they cannot be generalised and unequivocally recommended for any assessed area. When selecting methods, it is necessary to start with the specific natural and anthropogenic conditions of a given area. The presented methods were used on the example of loess lowland hill land with the occurrence of Chernozems and haplic Luvisols. The use of several methods for detecting erosion processes increases the objectivity of claims about currently ongoing soil removal processes.

The advantage of using the digitisation of surface erosion manifestations using aerial photos is the possibility of creating a reference layer by vectorisation in the ArcGIS environment, over which spatial units are created by overlay method. The spatial units are also the basic operational units for further analyses, including detailed field research of erosion areas. The disadvantage is that the light amoebic formations in the images do not necessarily have to be erosion surfaces in all cases, and therefore, verification in the field is needed. It was not possible to accurately locate and identify erosional processes on areas with agricultural cultures during the research. More specifically, it was in the large-scale ploughed fields and vineyards. Large-scale fields were not covered with veg- 
$\mathrm{T}$ a b l e 3. Selected carbon parameters in fractions of water-resistant macro-aggregates and their percent abundance

\begin{tabular}{|c|c|c|c|c|c|c|c|}
\hline \multirow[t]{2}{*}{$\begin{array}{l}\text { Part of the Slope/ } \\
\text { Fraction Size }\end{array}$} & $\begin{array}{c}>5 \\
\mathbf{m m}\end{array}$ & $\begin{array}{l}>3-5 \\
\mathrm{~mm}\end{array}$ & $\begin{array}{l}>2-3 \\
\mathrm{~mm}\end{array}$ & $\begin{array}{l}>1-2 \\
\text { mm }\end{array}$ & $\begin{array}{c}>0.5-1 \\
\mathrm{~mm}\end{array}$ & $\begin{array}{c}>0.25- \\
0.5 \\
\mathrm{~mm}\end{array}$ & $\begin{array}{c}<0.25 \\
\mathrm{~mm}\end{array}$ \\
\hline & \multicolumn{7}{|c|}{$\left(\mathrm{mg} \mathrm{kg}^{-1}\right)$} \\
\hline & \multicolumn{7}{|c|}{ Total Organic Carbon (TOC) } \\
\hline R1 & 10.990 & 8.880 & 8.860 & 11.270 & 10.980 & 8.090 & 5.580 \\
\hline R2 & 13.750 & 13.020 & 13.570 & 13.080 & 11.800 & 11.360 & 10.270 \\
\hline R3 & 21.010 & 17.580 & 18.380 & 19.460 & 17.950 & 16.040 & 15.210 \\
\hline $\mathrm{R} 4$ & 15.900 & 15.630 & 16.730 & 17.280 & 15.580 & 13.730 & 12.330 \\
\hline R5 & 13.960 & 14.280 & 14.430 & 14.730 & 14.180 & 11.650 & 9.250 \\
\hline R6 & 18.690 & 19.940 & 19.130 & 20.290 & 20.110 & 22.190 & 16.400 \\
\hline R7 & 16.050 & 17.240 & 17.000 & 17.240 & 17.640 & 16.880 & 13.630 \\
\hline R8 & 17.230 & 15.720 & 14.140 & 13.800 & 14.570 & 14.610 & 11.370 \\
\hline \multirow[t]{2}{*}{ R9 } & 9.540 & 11.190 & 10.970 & 12.150 & 11.900 & 10.590 & 7.950 \\
\hline & \multicolumn{7}{|c|}{ Labile Organic Carbon oxidised with $\mathrm{KMnO}_{4}\left(\mathrm{C}_{t}\right)$} \\
\hline R1 & 778 & 691 & 695 & 731 & 682 & 465 & 277 \\
\hline R2 & 1.203 & 1.186 & 1.070 & 1.124 & 1.118 & 911 & 730 \\
\hline R3 & 3.270 & 1.593 & 2.019 & 1.653 & 1.463 & 1.683 & 987 \\
\hline $\mathrm{R} 4$ & 1.622 .2 & 1.656 .1 & 1.480 .3 & 1.646 .5 & 1.763 & 1607.6 & 1.362 .7 \\
\hline R5 & 949.9 & 1.009 .1 & 902.9 & 1.029 .5 & 950.1 & 936.1 & 670.6 \\
\hline R6 & 1.061 .5 & 1.176 .1 & 1.144 .1 & 1.623 .2 & 907.1 & 1784.5 & 1127 \\
\hline R7 & 1.354 & 1.711 & 1.781 & 1.935 & 1.754 & 2.108 & 2.150 \\
\hline R8 & 679 & 924 & 922 & 969 & 1.094 & 1.116 & 1.148 \\
\hline \multirow[t]{2}{*}{ R9 } & 617 & 734 & 923 & 1.102 & 874 & 1.027 & 1.092 \\
\hline & \multicolumn{7}{|c|}{ Non-labile Organic Carbon (NLC) } \\
\hline R1 & 10.212 & 8.189 & 8.165 & 10.539 & 10.298 & 7.625 & 5.303 \\
\hline R2 & 12.547 & 11.834 & 12.500 & 11.956 & 10.682 & 10.449 & 9.540 \\
\hline R3 & 17.740 & 15,987 & 16.361 & 17.807 & 16.487 & 14.357 & 14.223 \\
\hline $\mathrm{R} 4$ & 14.277 .8 & 13.973 .9 & 15.249 .7 & 15.633 .5 & 13.817 .0 & 12.122 .4 & 10.967 .3 \\
\hline R5 & 13.010 .1 & 13.270 .9 & 13.527 .1 & 13.700 .5 & 13.229 .9 & 10.713 .9 & 8.579 .4 \\
\hline R6 & 17.628 .5 & 18.763 .9 & 17.985 .9 & 18.666 .8 & 19.202 .9 & 20.405 .5 & 15.273 .0 \\
\hline R7 & 14.696 & 15.529 & 15.219 & 15.305 & 15.886 & 14.772 & 11.480 \\
\hline R8 & 16.551 & 14.796 & 13.218 & 12.831 & 13.476 & 13.494 & 10.222 \\
\hline \multirow[t]{2}{*}{ R9 } & 8.923 & 10.456 & 10.047 & 11.048 & 11.026 & 9.563 & 6.858 \\
\hline & \multicolumn{7}{|c|}{ Percentage abundance of dry-sieved macro-aggregates fractions } \\
\hline \multirow{2}{*}{$\begin{array}{l}\text { Part of the Slope/ } \\
\text { Fraction Size }\end{array}$} & $>7 \mathrm{~mm}$ & $\begin{array}{l}>5-7 \\
\mathbf{m m}\end{array}$ & $\begin{array}{c}>3-5 \\
\mathrm{~mm}\end{array}$ & $\begin{array}{c}>1-3 \\
\mathrm{~mm}\end{array}$ & $\begin{array}{c}>0.5-1 \\
\mathrm{~mm}\end{array}$ & $\begin{array}{l}>0.25- \\
0.5 \mathrm{~mm}\end{array}$ & $\begin{array}{c}<0.25 \\
\mathrm{~mm}\end{array}$ \\
\hline & \multicolumn{7}{|c|}{$\%$} \\
\hline $\mathrm{R} 1$ & 13.08 & 11.49 & 14.58 & 20.70 & 17.12 & 9.65 & 13.39 \\
\hline R2 & 12.36 & 16.55 & 18.23 & 22.82 & 13.74 & 7.27 & 9.04 \\
\hline R3 & 9.86 & 17.03 & 21.16 & 28.70 & 13.18 & 4.55 & 5.52 \\
\hline R4 & 47.03 & 11.84 & 12.32 & 14.89 & 7.99 & 2.95 & 2.99 \\
\hline R5 & 27.05 & 11.28 & 13.90 & 19.76 & 14.93 & 6.49 & 6.58 \\
\hline R6 & 25.74 & 7.69 & 8.54 & 9.61 & 5.11 & 3.20 & 40.12 \\
\hline R7 & 0.68 & 3.70 & 5.34 & 6.46 & 11.60 & 23.06 & 49.16 \\
\hline R8 & 0.80 & 1.32 & 3.20 & 3.48 & 6.74 & 22.34 & 62.12 \\
\hline R9 & 2.42 & 4.86 & 9.54 & 21.40 & 20.00 & 21.00 & 20.78 \\
\hline
\end{tabular}

Notes: R1, R4 and R7 - upper convex part; R2, R5 and R8 - slope; R3, R6 and R9 - accumulative concave part. 
T a b l e 4. Chosen parameters of the soil structure.

\begin{tabular}{|l|c|c|c|}
\hline $\begin{array}{l}\text { Part of the Slope/ } \\
\text { Parameters }\end{array}$ & $\begin{array}{c}\text { Soil Structure } \\
\text { Vulnerability Coefficient } \\
\left(\mathbf{K}_{\mathbf{v}}\right)\end{array}$ & Index of Crusting $\left(\mathbf{I}_{\mathbf{c}}\right)$ & $\begin{array}{c}\text { Critical Soil Organic } \\
\text { Matter Content } \\
\left(\mathbf{S}_{\mathbf{t}}\right)\end{array}$ \\
\hline R1 & 1.441 & 1.477 & 1.706 \\
\hline R2 & 1.343 & 1.011 & 2.911 \\
\hline R3 & 1.204 & 0.689 & 3.913 \\
\hline R4 & 2.319 & 3.94 & 0.819 \\
\hline R5 & 0.915 & 2.557 & 1.484 \\
\hline R6 & 1.054 & 3.809 & 1.007 \\
\hline R7 & 2.695 & 3.537 & 0.881 \\
\hline R8 & 3.346 & 2.019 & 1.849 \\
\hline R9 & 1.644 & 2.765 & 1.283 \\
\hline
\end{tabular}

Notes: R1, R4 and R7 - upper convex part; R2, R5 and R8 - slope; R3, R6 and R9 - accumulative concave part.

T a b l e 5. Total organic carbon and selected quantitative and qualitative parameters of soil organic matter.

\begin{tabular}{|l|c|c|c|c|c|c|c|c|c|}
\hline & $\begin{array}{c}\text { Total } \\
\text { Organic } \\
\text { Carbon }\end{array}$ & $\begin{array}{c}\text { Cold Water } \\
\text { Extractable } \\
\text { Organic } \\
\text { Carbon }\end{array}$ & $\begin{array}{c}\text { Hot Water } \\
\text { Extractable } \\
\text { Organic } \\
\text { Carbon }\end{array}$ & $\begin{array}{c}\text { Labile } \\
\text { Organic } \\
\text { Carbon }\end{array}$ & $\begin{array}{c}\text { Humic } \\
\text { Substance } \\
\text { Carbon }\end{array}$ & $\begin{array}{c}\text { Humic Acid } \\
\text { Carbon } \\
\left(\mathbf{C}_{\text {HA }}\right)\end{array}$ & $\begin{array}{c}\text { Fulvic Acid } \\
\text { Carbon } \\
\left(\mathbf{C}_{\mathrm{FA})}\right.\end{array}$ & $\begin{array}{c}\mathbf{C}_{\mathrm{HA}} / \mathbf{C}_{\mathrm{FA}} \\
\left.\text { Ratio }^{-1}\right)\end{array}$ \\
\hline RL1 & 1.366 & 252.25 & 416.05 & 976 & 36.38 & 19.84 & 16.54 & 1.03 \\
\hline RL2 & 1.130 & 343.98 & 554.58 & 885 & 37.52 & 17.26 & 20.27 & 0.72 \\
\hline RL3 & 0.933 & 217.86 & 311.46 & 764 & 38.69 & 19.08 & 19.61 & 0.78 \\
\hline RL4 & 0.738 & 263.72 & 427.52 & 649 & 35.77 & 23.58 & 12.20 & 1.68 \\
\hline RL5 & 0.963 & 447.18 & 587.58 & 850 & 36.14 & 20.25 & 15.89 & 1.67 \\
\hline RL6 & 1.202 & 470.11 & 1218.91 & 825 & 36.19 & 21.71 & 14.48 & 1.70 \\
\hline RL7 & 1.217 & 412.78 & 822.28 & 986 & 36.89 & 18.57 & 18.32 & 1.60 \\
\hline RL8 & 1.337 & 217.86 & 592.26 & 1074 & 36.35 & 18.70 & 17.65 & 1.53 \\
\hline RL9 & 1.651 & 194.93 & 674.63 & 1008 & 35.61 & 21.26 & 14.35 & 1.09 \\
\hline RL10 & 1.378 & 114.66 & 301.86 & 1211 & 39.62 & 26.99 & 12.63 & 1.34 \\
\hline RL11 & 1.456 & 149.06 & 617.06 & 1301 & 24.24 & 23.42 & 13.32 & 1.37 \\
\hline RL12 & 1.592 & 149.06 & 500.06 & 1231 & 34.48 & 19.91 & 14.57 & 1.27 \\
\hline RL13 & 1.676 & 137.59 & 535.39 & 1289 & 32.76 & 19.93 & 12.83 & 1.64 \\
\hline
\end{tabular}

Note: RL1 to RL13 are soil sampling localities on slopes.

etation during the mapping, and the newly established intensively used bleak vineyards uncovered erosional areas.

Modelling of water erosion is an effective method used in research. It is an effective way of protecting the soil by which the user regulates the management to minimise soil mass loss. Model results may not match the actual occurrence of erosion in space. This contention was confirmed in the synthesis of erosion endangered areas and the result of modelling of poten- 
tial average annual soil loss (Fig. 4). The models also do not feature precise expression of the movement of the material along the slope, and they do not determine the exact location of the soil particles in the plot. It is not appropriate to use them for a shorter period than the season, respectively, to determine the soil loss from a single rainfall event or sudden snow heating.

Identification and verification of water erosion using soil probes is a relatively effective way of identifying real erosional processes. The advantage is also the understanding of landscape ecological, geomorphological connections and relationships in the landscape, which should be included in the proposals and principles for sustainable land use. However, using the method requires expertise and experience in field soil research. The method has its limitations, which result from real conditions in a given part of the growing season and conditions of soil state (optimal soil moisture, vegetation height, etc.).

When identifying erosional processes in the context of SOM and soil structure analysis, unlike other methods, not only quantitative but also qualitative changes in soil erosion endangered soil properties are determined. The difficulty of the method is that it requires precise analyses in laboratory conditions and field sampling is bound by the optimal current soil moisture.

It is not possible to determine which of the methods of soil loss detection used is more significant. The methods used are complementary. Identification of spatial distribution of erosion areas and modelling are helpful in quantitatively define erosion areas. The use of soil probes and analysis of SOM are helpful in verify qualitative changes in soil during the process of water erosion.

The contribution of the research is also the identification of erosional processes in relation to the dynamics of land use. On the basis of this, it can be assumed whether the development or the elimination of erosional processes or their elimination can potentially occur in the area. The importance of using a combination of various methods for research of erosional processes in the landscape is a suitable tool in a precise agriculture. Accurate localisation of endangered surface by erosion with the possibility of proposing an adequate soil erosion protection corresponds to the principles of the CAP. Farmers must respect Good Agricultural and Environmental Conditions (GAEC), which are linked to direct income support. Soil GAECs adopted for the European Union 2014-2020 planning period, designed to prevent soil erosion through appropriate measures, include standards that should be respected. However, the opposite has been shown in practice. Despite the fact that crops are being reduced in agriculture; soil, landscape, environment and other properties are damaged; and profit reduction, standards are rarely abided. The accurate detection of endangered surface by erosion will allow the farmer to invest less costs in soil protection than when trying to provide protection on a whole land block, which often leads to inefficient loss of energy and funds. It leads to an increase in the cost of the whole company. The costs of technical landscaping, infrastructure repair and water treatment are increasing.

\section{Acknowledgements}

This paper was supported by project APVV-17-0377, Assessment of recent changes and trends in agricultural landscape of Slovakia, and project KEGA No. 025UKF-4/2019, Erosion-accumulation processes as a limiting factor of agricultural landscape. 


\section{References}

Abera, W. \& Assen M. (2019). Dynamics of selected soil quality indicators in response to land use/cover and elevation variations in Wanka watershed, northwestern Ethiopian highlands. Ekológia (Bratislava), 38(2), 126-139, 2019. DOI: $10.2478 /$ eko-2019-0010.

Act No. 220/2004 Coll. on the protection and use of agricultural land and on the amendment of Act No. 245/2003 Coll. on Integrated Pollution Prevention and Control and on amendments to certain acts.

Al-Abadi, A.M.A., Ghalib, H.B. \& Al-QurnawI W.S. (2016). Estimation of soil erosion in northern Kirkuk governorate, Iraq using RUSLE, Remote sensing and GIS. Carpathian Journal of Earth and Environmental Sciences, 11(1), 153-166.

Bielek, P. (2017). Soil science (in Slovak.) Nitra: SPU.

Biswas, S., Sudhakar, S. \& Desai V.R. (1999). Prioritization of sub-watersheds based on morphometric analysis of drainage basin: a remote sensing and GIS approach. Journal of the Indian Society of Remote Sensing, 27(3), 155-166. DOI: 10.1007/BF02991569.

Bouaziz, M., Leidig, M. \& Gloaguen R. (2011). Optimal parameter selection for qualitative regional erosion risk monitoring: A remote sensing study of SE Ethiopia. Geoscience Frontiers, 2(2), 237-142. DOI: 10.1016/j. gsf.2011.03.004.

Conforti, M., Buttafuoco, G., Leone, A.P., Aucelli, P.P.C., Robustelli, G. \& Scarciglia F. (2013). Studying the relationship between water-induced soil erosion and soil organic matter using Vis-NIR spectroscopy and geomorphological analysis: A case study in southern Italy. Catena, 110, 44-58. DOI: 10.1016/j.catena.2013.06.013.

Faltan, V., Krajčírovičová, L., Petrovič, F. \& Khun M. (2017). Detailed geoecological research of terroir with the focus on georelief and soil - a case study of Krátke Kesy vineyards. Ekológia (Bratislava), 36(3), 214-225. DOI: 10.1515/eko-2017-0018.

Fulajtár, E. \& Janský L. (2001). Soil water erosion and erosion protection (in Slovak). Bratislava: VÚPaOP.

Ilavská, B., Jambor, P. \& Lazúr R. (2005). Identification of endangered to soil quality by water and wind erosion and proposed measures (in Slovak). Bratislava: VÚPaOP.

Janeček, M., Dostál, T., Dufková, K.J., Dumbrovský, M., Hůla, J., Kadlec, V., Konečná, J., Kovář, P., Krása, J., Kubátová, E., Kobzová, D., Kudrnáčová, M., Novotný, I., Podhrázská, J., Pražan, J., Procházková, E., Středová, H., Toman, F., Vopravil, J. \& Vlasák J. (2012). Agricultural land erosion protection. Methodics (in Czech). Praha: Česká zemědělská univerzita.

Kenderessy, P. (2012). Soil loss assessment in an agricultural landscape and its utilization in landscape planning. Ekológia (Bratislava), 31(3), 309-321. DOI: 10.4149/ekol_2012_03_309.

Kirkby, M., Bracken, L. \& Reaney S. (2002). The influence of land use, soils and topography on the delivery of hillslope runoff to channels in SE Spain. Earth Surface Processes and Landforms, 27, 1459- 1473. DOI: 10.1002/esp.441.

Lal, R. \& Shukla M.K. (2004). Principles of soil physics. New York: CRC Press.

Lapin, M., Faško, P., Melo, M., Štastný, P. \& Tomlain, J. (2002). Climatic regions (in Slovak). In Atlas krajiny SR (pp. 95). Bratislava: MŽP SR, Banská Bystrica: SAŽP.

Li, Z., Liu, CH., Dong, Y., Chang, X., Nie, X., Liu, L., Xiao, H., Lu, Y. \& Zeng G. (2017). Response of soil organic carbon and nitrogen stocks to soil erosion and land use types in the Loess hilly-gully region of China. Soil Tillage Res., 166, 1-9. DOI: 10.1016/j.still.2016.10.004.

Malíšek, A. (1992). Optimal slope length depending on water erosion (in Slovak). In Vedecké práce (pp. 201-220). Bratislava: VÚPaOP.

Miklós, L., Krcho, J., Hrnčiarová, T., Matečný, I. \& Kozová M. (1997). Morphometric relief indicators and their usefulness of interpretation for planning processes (in Slovak). Bratislava: ÚKE SAV.

Panagos, P., Borrelli, P., Poesen, J., Ballabio, C., Lugato, E., Meusburger, K., Montanarella, L. \& Alewell C. (2015). The new assessment of soil loss by water erosion in Europe. Environmental Science \& Policy, 54, 438-447. DOI: 10.1016/j.envsci.2015.08.010.

Petlušová, V., Petluš, P. \& Hreško J. (2016). Identification of water erosion processes in agricultural land (in Slovak). Nitra: UKF.

Petlušová, V., Petluš, P. \& Hreško J. (2017). The effect of land use changes on soil erosion in the areas of Lubá and Belá (Hronská pahorkatina upland). Geografický Časopis, 69(3), 245-262.

Pintaldi, E., D’amico, M.E., Stanchi, S., Catoni, M., Freppaz, M. \& Bonifacio E. (2018). Humus forms affect soil susceptibility to water erosion in the Western Italian Alps. Applied Soil Ecology, 123, 478-483. DOI: 10.1016/j. apsoil.2017.04.007. 
Six, J., Callewaert, P., Lenders, S., De Gryze, S., Morris, S.J., Gregorich, E.G., Paul, E.A. \& Paustian K. (2002). Measuring and understanding carbon storage in afforested soils by physical fractionation. Soil Sci. Soc. Am. J., 66(6), 1981-1987. DOI: 10.2136/sssaj2002.1981.

Stankoviansky, M. (2000). Differentiated geomorphic effect of gully erosion due to large scale land use changes. In D. Balteanu, M. Ielenicz \& N. Popescu (Eds.), Geomorphology of the Carpatho-Balcan Region. Bucurest: Drobeta Turnu Severin.

Stankoviansky, M. (2001). Tillage erosion and its geomorphic effect with special regard to the Myjava-White Carpathian kopanitse area (in Slovak). Geografický Časopis, 53(2), 95-110.

Styk, J. (2002). Monitoring the impact of water erosion on changes in selected soil properties (in Slovak). In J. Kobza (Ed.), Monitoring pôd SR. Aktuálny stav a vývoj monitoringu pôd. Výsledky z Čiastkového monitorovacieho systému - Pôda za obdobie 1997-2001. Bratislava: VÚPaOP.

Šarapatka, B. \& Niggli U. (2008). Agriculture and landscape: The paths to alignment (in Czech). Olomouc: Univerzita Palackého.

Šarapatka, B., Cap, L. \& Bila P. (2018). The varying effect of water erosion on chemical and biochemical soil properties in different parts of Chernozem slopes. Geoderma, 314, 20-26. DOI: 10.1016/j.geoderma.2017.10.037.

Valla, M., Kozák, J. \& Ondráček V. (2000). Vulnerability of aggregates separated from selected anthorsols developed on reclaimed dumpsites. Rostlinná Výroba, 46, 563-568.

Wang, Y., Ran, L., Fang, N. \& Shi Z. (2018). Aggregate stability and associated organic carbon and nitrogen as affected by soil erosion and vegetation rehabilitation on the Loess Plateau. Catena, 167, 257-265. DOI: 10.1016/j. catena.2018.05.005.

Wischmeier, W.H. \& Smith D.D. (1978). Predicting rainfall erosion losses. Maryland: SEA USDA Hystaville.

Zachar, D. (1970). Soil erosion (in Slovak). Bratislava: SAV.

Zachar, D. (1982): Soil erosion. New York, Amsterdam, Oxford: Elsevier.

Zeleňáková, M. \& Jakubíková A. (2010). Modeling of erosion and transport processes. Ekológia (Bratislava), 29(1), 87-98. DOI: 10.4149/ekol_2010_01_87. 